\title{
Rancang Bangun Sistem Informasi Manajemen Kegiatan Penelitian di Politeknik Elektronika Negeri Surabaya
}

\author{
Kholid Fathoni ${ }^{1}$,Arna Fariza ${ }^{2}$,Y ufi Eko Firmansyah ${ }^{3}$ \\ Politeknik Elektronika Negeri Surabaya \\ 1'kholid@pens.ac.id, ${ }^{2}$ arna@pens.ac.id, ${ }^{3}$ yufieko@gmail.com
}

\begin{abstract}
ABSTRAK. Penelitian merupakan salah satu kewajiban Tri Dharma Perguruan Tinggi yang harus diselenggarakan oleh perguruan tinggi. Politeknik Elektronika Negeri Surabaya (PENS) sebagai institusi perguruan tinggi memiliki kewajiban menyelenggarakan kegiatan penelitian. Pengelolaan kegiatan penelitian di PENS selama ini masih bergantung pada aktivitas manual dalam mengumpulkan, menyimpan, mengolah serta menyajikan data penelitian. Hal ini menyebabkan beberapa masalah diantaranya: keterlambatan, ketidakakuratan, dan kehilangan data serta beban kerja berlebih bagi administrator, operator dan para stakeholder dalam mencari dan mengelola data penelitian. Oleh karena itu perlu dibangun suatu aplikasi sistem informasi penelitian berbasis web yang menangani pengelolaan berbagai data penelitian untuk mengatasi berbagai persoalan tersebut. Sistem berbasis elekronik ini menangani berbagai data master, pengumpulan data proposal, laporan kemajuan dan laporan akhir serta menangani transaksi seleksi proposal, monitoring dan evaluasi laporan kemajuan, serta seminar hasil, termasuk di dalamnya menangani proses review penelitian pada tiap tahapan tersebut. Sistem ini dibangun berbasis PHP framework serta basisdata MySQL. Hasil ujicoba sistem menunjukkan bahwa semua fungsi aplikasi berjalan sebagaimana skenario serta membantu para stakeholder penelitian untuk mengelola kegiatan penelitian di PENS.
\end{abstract}

Kata Kunci: penelitian, aplikasi, sistem informasi, PHP framework, basisdata MySQL

ABSTRACT. Research is one of the obligations of the Higher Education Tri Dharma that must be carried out by universities. Politeknik Elektronika Negeri Surabaya (PENS) as a tertiary institution has the obligation to conduct research activities. Management of research activities in PENS so far still depends on manual activities in collecting, storing, processing and presenting research data. This causes several problems including: delays, inaccuracies, and loss of data and excessive workload for administrators, operators and stakeholders in finding and managing research data. Therefore it is necessary to build a web-based research information system application that handles the management of various research data to overcome these problems. This electronic-based system handles a variety of master data, proposal data collection, progress reports and final reports as well as handling proposal selection transactions, monitoring and evaluating progress reports, as well as seminar results, including handling the research review process at each of these stages. This system is built based on PHP framework and MySQL database. The system test results show that all application functions run as scenarios and help research stakeholders manage research activities in PENS.

Keywords: research, applications, information systems, PHP frameworks, MySQL databases

\section{PENDAhUluAN}

Kegiatan penelitian merupakan kewajiban perguruan tinggi untuk menyelenggarakannya, di samping melaksanakan pendidikan dan pengabdian masyarakat[1]. Para ahli mendefinisikan pengertian penelitian dengan redaksi yang berbeda. Fellin, Tripodi dan Meyer mengemukakan bahwa penelitian adalah suatu cara sistematik untuk maksud meningkatkan, memodifikasi dan mengembangkan pengetahuan yang dapat di sampaikan (dikomunikasikan) dan diuji (diverifikasi) oleh peneliti lain [2]. Dalam buku Introduction to Research, Hillway mengemukakan bahwa penelitian tidak lain dari suatu metode studi yang dilakukan seseorang melalui penyelidikan yang hati-hati dan sempurna terhadap suatu masalah, sehingga diperoleh pemecahan yang tepat terhadap permasalahan tersebut [3]. Penelitian di perguruan tinggi diarahkan untuk mengembangkan ilmu pengetahuan dan teknologi, serta meningkatkan kesejahteraan masyarakat dan daya saing bangsa. Dalam pasal tersebut juga ditegaskan bahwa pengabdian kepada masyarakat merupakan kegiatan sivitas akademika dalam mengamalkan dan membudayakan ilmu pengetahuan dan teknologi untuk memajukan kesejahteraan umum dan mencerdaskan kehidupan bangsa[4].

Dengan berkembangnya teknologi komputer [5] yang sangat pesat, distribusi informasi kepada banyak pengguna internet dapat dilakukan dalam waktu singkat. Keberadaan sistem informasi berbasis elektronik memudahkan pengguna dalam mengelola berbagai data utama dan transaksi. Sistem Informasi merupakan gabungan beberapa komponen yang saling berelasi yang berfungsi mengumpulkan, mengolah, menyimpan, dan mendistribusikan data dan informasi serta memberikan sebuah mekanisme timbal balik untuk mencapai 
tujuan[6]. Sistem informasi bukan hanya fokus pada penggunaan organisasi teknologi informasi dan komunikasi (TIK), tetapi juga cara orang berinteraksi dengan teknologi informasi dan komunikasi dalam mendukung proses bisnis.[7]

Terdapat perbedaan antara sistem informasi, komputer sistem TIK, dan proses bisnis. Sistem informasi berbeda dari teknologi informasi. Sistem informasi memiliki komponen TIK di dalamnya. Hal ini berkaitan dengan tujuan bagaimana memanfaatkan teknologi informasi untuk mendukung proses bisnis. Sistem informasi memiliki perbedaan dengan proses bisnis karena sistem informasi membantu para stakeholder untuk mengendalikan kinerja proses bisnis[8].

Sistem informasi merupakan salah satu dari sistem kerja. Sistem kerja merupakan sistem di mana manusia atau mesin melakukan pekerjaan dengan menggunakan sumber daya untuk memproduksi produk atau jasa bagi pelanggan. Sistem informasi merupakan sistem kerja yang kegiatannya ditujukan untuk menangkap, mengirim, menyimpan, mengambil, memanipulasi dan menampilkan informasi [9]. Salah satu bentuk sistem informasi yaitu sistem informasi manajemen, yang mempunyai tujuan utama menghasilkan informasi yang dapat digunakan dalam pengambilan keputusan manajemen [10]. Kegiatan penelitian membutuhkan aplikasi sistem informasi manajemen untuk mengelola data-data master penelitian berupa: data peneliti, data kategori kegiatan penelitian, serta data usulan penelitian dan lain-lain. Sistem ini diperlukan untuk penanganan transaksi unggah proposal, laporan kemajuan dan laporan akhir. Aplikasi ini juga diperlukan terutama dalam proses penilaian oleh reviewer penelitian pada saat seleksi proposal, penilaian monitoring evaluasi serta penilaian seminar hasil. Hasil dari penilaian penelitian berbasis aplikasi ini menentukan kebijakan manajemen dalam mengambil keputusan terkait dengan proposal terpilih; evaluasi MONEV serta hasi penelitian yang digunakan untuk penentuan penerima pendanaan penelitian pada periode berikutnya. Oleh karena itu PENS sangat memerlukan sistem informasi manajemen untuk mengelola kegiatan penelitian dengan mudah, cepat dan akurat sehingga menambah kualitas pelayanan dan kinerja PENS bagi para stakeholder penelitian.

Sistem ini dikembangkan berbasis multiplatform alias daring atau online. Sistem daring memerlukan web server. Web server biasanya sudah dilengkapi dengan mesin penerjemah bahasa skrip sehingga dapat menyediakan layanan web dinamis dengan mendayagunakan pustaka tambahan seperti PHP [11]. Aplikasi ini dibangun dengan berbasis database yang merupakan suatu sistem yang mengintegrasikan koleksi data yang saling berhubungan dan dapat melayani beberapa aplikasi sekaligus[12]. Bahasa pemrograman yang digunakan dalam pembuatan aplikasi ini adalah PHP. Penggunaan PHP bertujuan untuk membuat aplikasi yang dapat berjalan pada teknologi web browser, namun proses secara keseluruhan dijalankan di atas web server[13]. Penggunaan PHP berbasis framework codeigniter diperlukan untuk meningkatkan reusability serta kemudahan pengembangan sistem aplikasi ini di masa mendatang. Framework merupakan gabungan perintah yang membentuk aturan tertentu dan saling berinteraksi satu sama lain sehingga programmer tidak disulitkan dengan kode perintah / fungsi dasar [14].

Sehubungan dengan topik ini, Almas Rahmah Arimi Shodiq sebelumnya telah membuat aplikasi sistem informasi penelitian dan pengabdian kepada masyarakat dengan standar BAN-PT berbasis web menggunakan metode waterfall atau Software Development Life Cycle[15]. Sistem ini lebih fokus untuk keperluan standar penelitian dan pengabdian mengacu kepada pedoman BAN-PT yang memiliki perbedaan dengan kebutuhan pengelolaan penelitian pada Perguruan Tinggi.

Selain itu Ivan Williandy dkk juga telah membangun sistem informasi penelitian dan pengabdian kepada masyarakat fakultas Teknik universitas lampung menggunakan php dan MySQL dengan pendekatan waterfall [16]. Penelitian ini menitikberatkan pada penyimpanan data-data utama saja namun tidak menangani transaksi penilaian oleh reviewer.

Selanjutnya Desi Ratnasari dkk juga mengembangkan penelitian dengan topik analisis dan perancangan aplikasi sistem informasi penelitian dan pengabdian masyarakat LPPM STT Terpadu Nurul Fikri[17]. Penelitian ini juga hanya menitikberatkan pada penyimpanan data-data administrasi penelitian dan pengabdian, namun tidak memiliki fitur yang dapat menangani transaksi penilaian penelitian oleh reviewer. Adapun sistem yang dibangun oleh penulis dalam penelitian ini yaitu sistem informasi manajemen penelitian yang menangani berbagai data master penelitian termasuk pengumpulan data proposal, laporan kemajuan dan laporan akhir serta menangani transaksi penilaian oleh reviewer yang meliputi: seleksi proposal, monitoring dan evaluasi, serta seminar hasil penelitian. Termasuk didalamnya penugasan dan plotting reviewer serta rekapitulasi hasil penilaian. 


\section{METODE}

Obyek penelitian dalam pembuatan sistem informasi manajemen kegiatan penelitian ini difokuskan pada proses kegiatan penelitiannya, mulai dari awal hingga akhir. Pada perencanaan sistem informasi manajemen kegiatan penelitian dapat dibagi menjadi tahapan berikut ini yaitu :

1. Sistem Kerja Aplikasi Secara Umum

2. Pengumpulan Data

3. Perancangan Diagram Sistem

4. Pembuatan Tabel Relasional

5. Perancangan Database

\section{Sistem Kerja Aplikasi secara Umum}

Sistem ini dimulai dari posisi peneliti akan menerima notifikasi agenda atau kegiatan selanjutnya yang akan dilakukan untuk menyelesaikan penelitiannya. Ada juga pada beberapa user dengan hak khusus seperti operator dan manajer P3M yang juga menerima notifikasi untuk laporan kemajuan dan proposal.Semua data penelitian didapat dari Peneliti, DIKTI, dan Staf P3M, lalu disimpan ke database sistem informasi yang nantinya diolah. Data yang diterima oleh sistem akan diolah informasinya dan dibagi ke berdasarkan target. Secara umum kegiatan penelitian akan ditampilkan pada website. Gambaran sistem kerja aplikasi secara umum ditunjukkan diagram berikut.

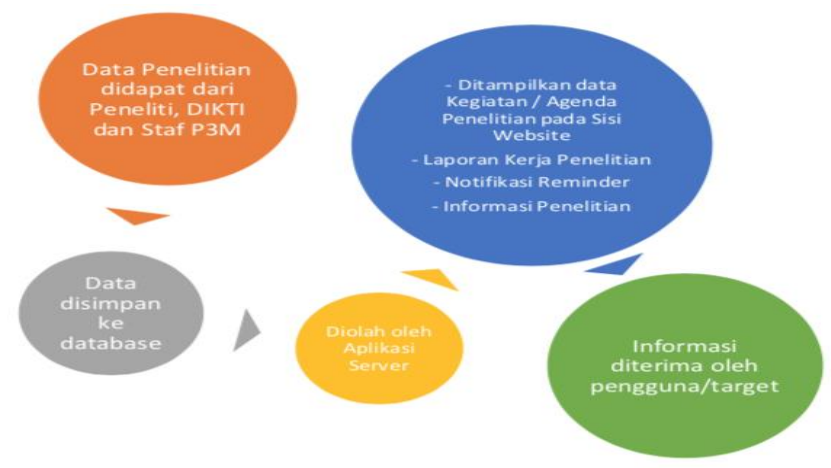

Gambar 1. Sistem Kerja Aplikasi secara Umum

Struktur menu aplikasi ini terdiri atas 2 (dua) bagian yaitu frontend dan backend. Frontend terdiri atas beberapa menu yaitu home, berita, penelitian, panduan, sedangkan bagin backend terdiri atas beberapa menu yaitu : dashboard, log, notifikasi, agenda, reminder, laporan, berkas, penelitian, review dan manajemen. Struktur menu ditunjukkan gambar 2 sebagai berikut.

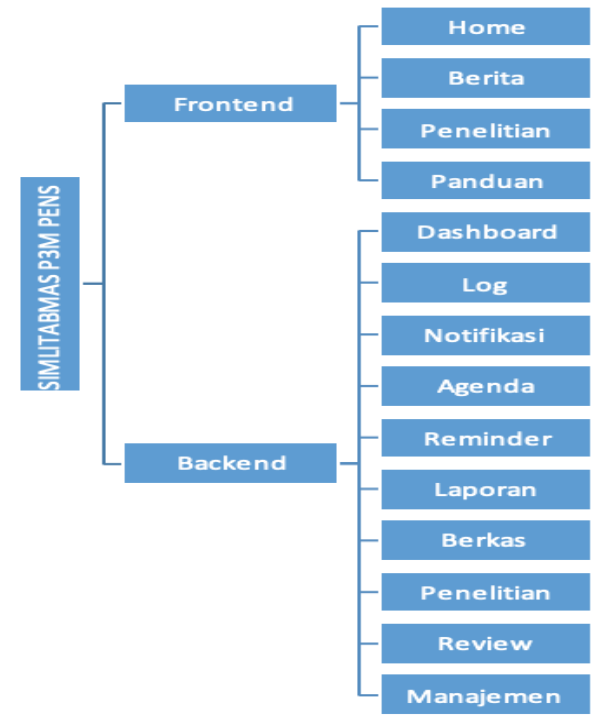

Gambar 2.Sitemap Aplikasi 


\section{Pengumpulan Data}

Dalam pengumpulan data, Informasi umum mengenai Penelitian dan sumber daya didapat dari P3M

PENS. Data-data yang dibutuhkan meliputi :

1. Data Sumber Daya Peneliti

2. Data Grup Riset

3. Data Pusat Riset

4. Data Kriteria Penilaian

5. Data Kriteria Penelitian berdasarkan Skim

6. Data Kriteria Ketua dan AnggotaPeneliti

7. Data Program Studi

8. Data Form yang digunakan untuk Penilaian dan Usulan

\section{Perancangan Diagram Sistem}

Perancangan sistem dibuat berdasarkan hasil analisis pada sistem. Dalam sistem informasi manajemen ini akan dibahas tentang perancangan proses dengan Use Case Diagram (UCD) dan Data Flow Diagram (DFD). UCD berorientasi perilaku aktor yang nantinya muncul pada sistem, perilaku bisa dalam bentuk permintaan atau memberikan suatu hal. Sedangkan DFD ini merupakan alat perancangan sistem yang berorientasi pada alur data dengan konsep dekomposisi sehingga dapat digunakan untuk penggambaran analisis maupun rancangan sistem yang mudah dikomunikasikan oleh profesional sistem kepada pemakai maupun pembuat program.

Use Case Diagram

Dosen merupakan actor yang berperan sebagai pengunjung biasa yang mengakses website dengan melakukan login terlebih dahulu sebagai dosen. User ini memiliki hak akses seperti mengelola kegiatan penelitian yang dilakukannya, mengelola data pribadi, mengelola laporan kemajuan, mengelola berkas penelitian, melihat hasil penilaian, pengajuan penelitian, melihat kontrak dan SK yang dikeluarkan, menentukan reminder dan menerima notifikasinya. Selain itu, staf P3M merupakan aktor yang melayani keseluruhan kegiatan yang berkaitan dengan kegiatan penelitian yang akan, sedang dan sudah dilaksanakan. Contoh kerjanya seperti memberikan informasi penelitian, berita, informasi seleksi dan berkas-berkas terkait. Sedangkan reviewer atau penilai merupakan aktor dengan hak khusus juga yang diberikan oleh pihak P3M kepada dosen yang ditunjuk, mempunyai wewenang untuk melakukan penilaian secara substantif dan juga memberikan masukan kepada dosen yang melakukan penelitian.

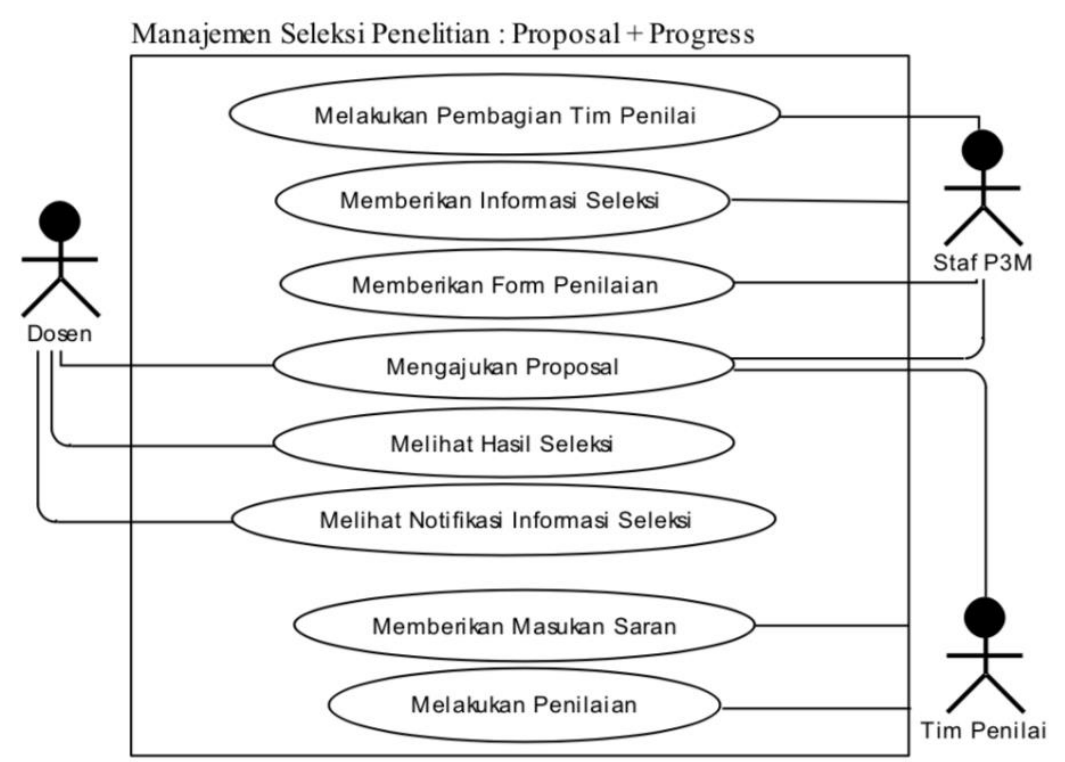

Gambar 3. Use Case Diagram Manajemen Seleksi Proposal dan MONEV

Sedangkan administrator sama halnya dengan aktor Dosen yang juga harus login terlebih dahulu. Aktor ini juga memiliki keseluruhan hak akses terhadap sistem ini, diantaranya seperti mengelola user, reminder, berita, data dosen, data jurusan, data berkas, log, dan kontrak serta SK yang dikeluarkan. 


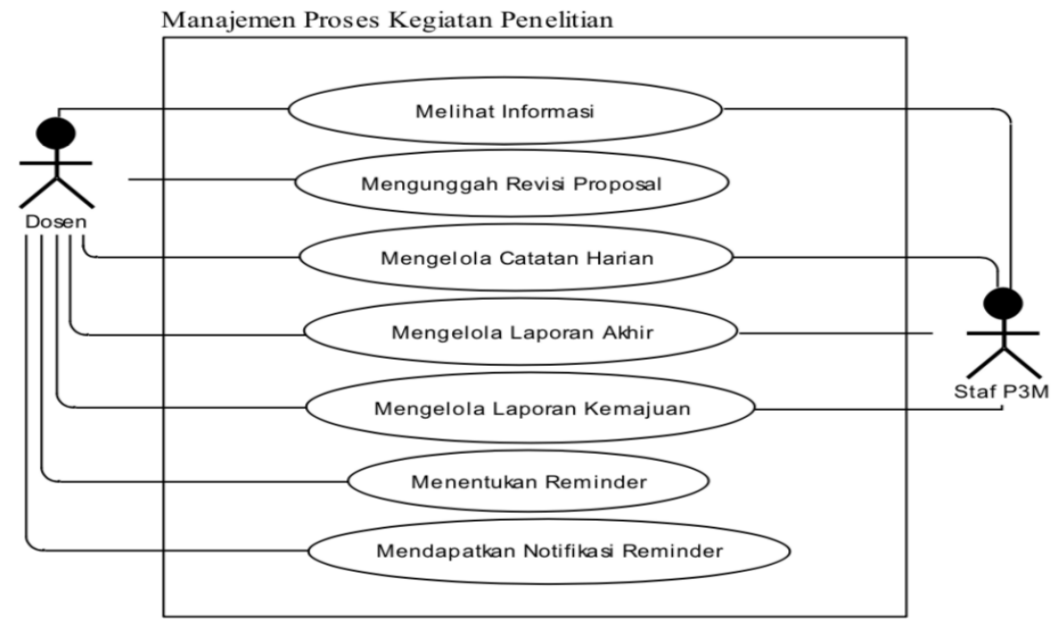

Gambar 4. Use Case Diagram Manajemen Proses Kegiatan Penelitian

Pimpinan merupakan aktor tertinggi juga namun hanya memiliki beberapa hak akses yang lebih mengarah pada proses pengawasan dan hasil penelitian yang dilakukan.

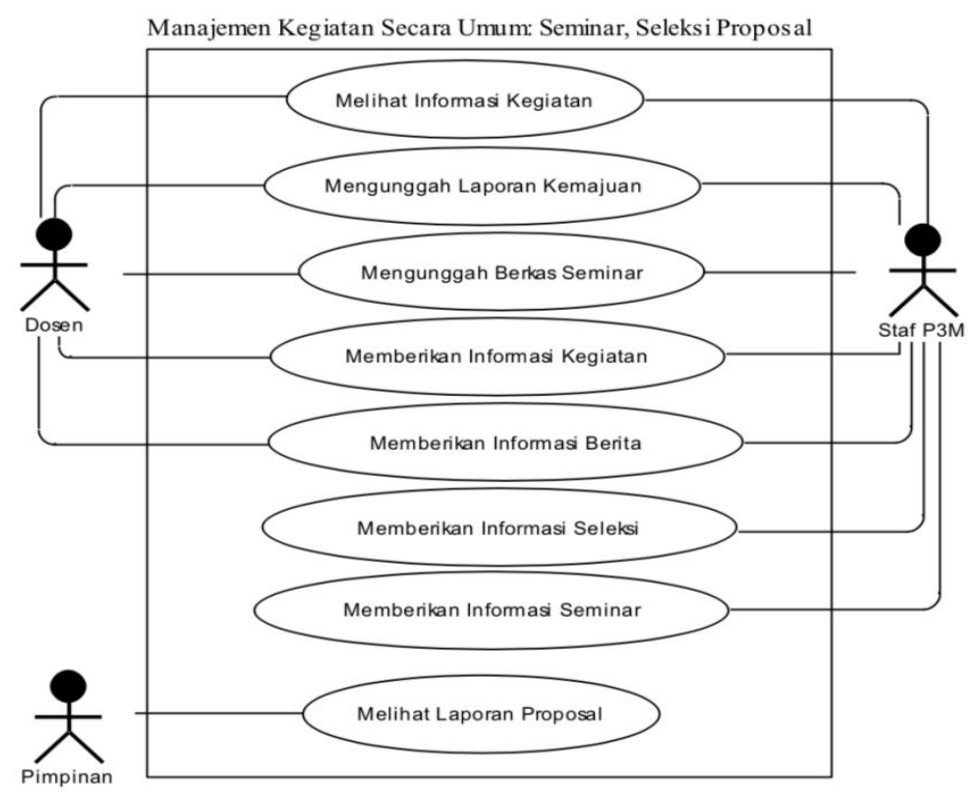

Gambar 5. Use Case Diagram Manajemen Kegiatan secara Umum

\section{Data Flow Diagram}

Terdapat lima entitas yang berhubungan dengan sistem ini yaitu Administrator, Staf P3M, Pimpinan P3M, Tim Penilai, dan Dosen. Entitas Administrator bertugas untuk melakukan kontrol penuh terhadap sistem dan memberikan data-data yang diperlukan. Entitas Staf P3M bertugas untuk melayani entitas Dosen, melakukan pembagian tim penilai, memberikan informasi terbaru tentang P3M dari berupa berita sampai agenda. Entitas Pimpinan P3M melakukan pengawasan terhadap semua kegiatan penelitian dan dapat melakukan rilis dan konfirmasi terhadap hasil dari kegiatan penilaian proposal usulan penelitian baru dan hasil akhirnya. Dan Entitas Dosen dapat melakukan proses pengajuan usulan penelitian baru, dan manajemen kegiatan penelitian yang sedang berlangsung. Sistem mengolah data-data yang diberikan oleh tiap Entitas dan hasil olahan data tersebut disampaikan kepada target entitas atau pengguna yang telah ditentukan, sesuai dengan hak akses masing-masing.

DFD level 1 dari sistem informasi manajemen kegiatan penelitian terdapat kurang lebih sepuluh proses yang utama (lihat gambar 7) yaitu proses informasi civitas, yang merupakan proses untuk melakukan 
manajemen data dosen, jurusan, dan sumber daya peneliti yang lain, yang bisa melakukan penambahan, modifikasi, hapus adalah entitas Administrator. Lalu selanjutnya ada proses pengolahan data kontrak, yang menangani arus informasi kontrak dan surat keputusan yang telah disetujui oleh pimpinan P3M dan dapat dilihat oleh dosen dan staf P3M.

Pada proses kegiatan P3M, meliputi manajemen kegiatan secara umum yang dilaksanakan dalam lingkup P3M PENS, yang datanya ditangani oleh staf P3M. Selanjutnya ada pengolahan berkas laporan yang meliputi pengiriman berkas laporan seperti kemajuan, anggaran, dan akhir, proses ini menghubungkan semua entitas yang ada. Berkas akan disimpan pada server, jika didapati ada berkas yang sama, maka berkas lama akan diganti dengan yang baru. Pada proses kelola data user, yang menangani adalah administrator, pada proses ini administrator dapat menentukan user akan memiliki role sebagai apa, apakah dosen, staf, administrator atau pimpinan. User juga dapat diberikan hak khusus yaitu sebagai tim penilai.

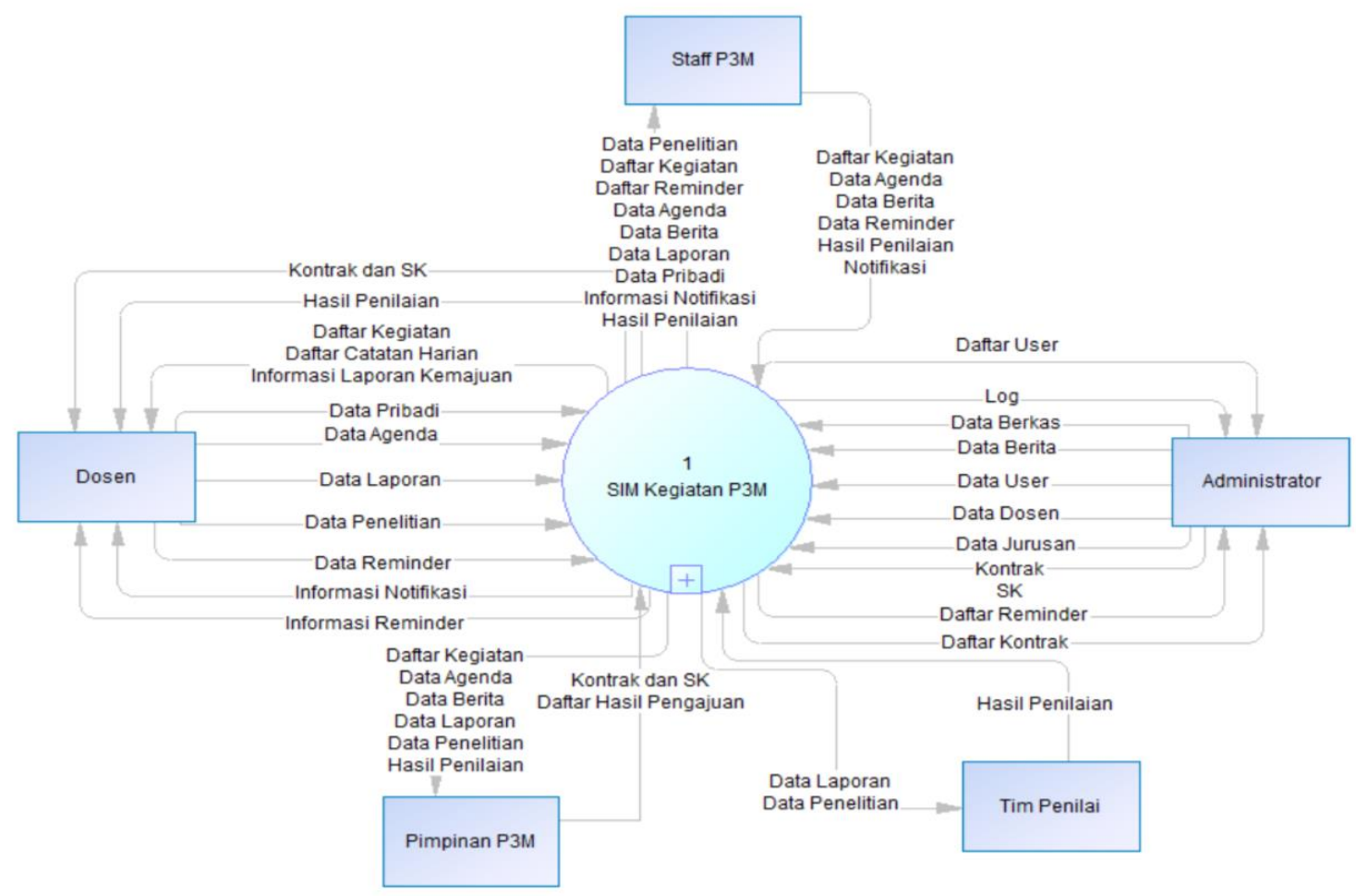

Gambar 6. Context Diagram Sistem Informasi Manajemen Penelitian PENS

Untuk proses reminder berisi manajemen pengingat bagi user itu sendiri. User dapat menentukan batas akhir tanggal yang dipilih, nanti selama 7 hari dari batas akhir yang telah ditentukan user akan mendapatkan notifikasi. Selain untuk diri sendiri, reminder ini juga secara default pada sistem ini, jadi misalkan ada informasi agenda ataupun berita maka notifikasi akan dikirimkan kepada target.

Untuk proses penilaian, pertama staf P3M menentukan siapa saja dosen yang akan menjadi tim penilai dan pada penelitian apa saja, jadi anggota tim peneliti bisa menilai penelitian yang berbeda. Penilaian terdapat pada dua jenis kegiatan, yaitu pada usulan penelitian baru dan kemajuan (progres). Form yang diisi pun nanti berbeda, dengan bobot dan range nilai yang berbeda. Pada proses ini, penilai juga dapat memberikan pendapat bagi peneliti.

Pada proses penambahan penelitian, peneliti harus melengkapi syarat-syarat yang telah diberikan, mulai dari syarat untuk ketua peneliti, anggota peneliti, dan penelitian itu sendiri. Penelitian dibagi menjadi 3 tingkatan (skim). Dengan syarat yang berbeda di tiap tingkatnya.

Proses pencatatan log selalu dijalankan pada proses-proses penting pada sistem ini, tujuannya satu agar ada jejak bilamana ada kejanggalan yang terjadi pada sistem yang disebabkan oleh penggunanya ataupun aplikasinya sendiri. 
Proses terakhir adalah pengolahan berita, berita pada sistem ini dapat dibuat oleh tiga entitas yaitu dosen, staf P3M dan administrator. Setiap entitas memiliki perbedaan pada fitur yang disematkan. Seperti adanya pageview counter di entitas staf P3M dan administrator, sedangkan di entitas dosen tidak ada.

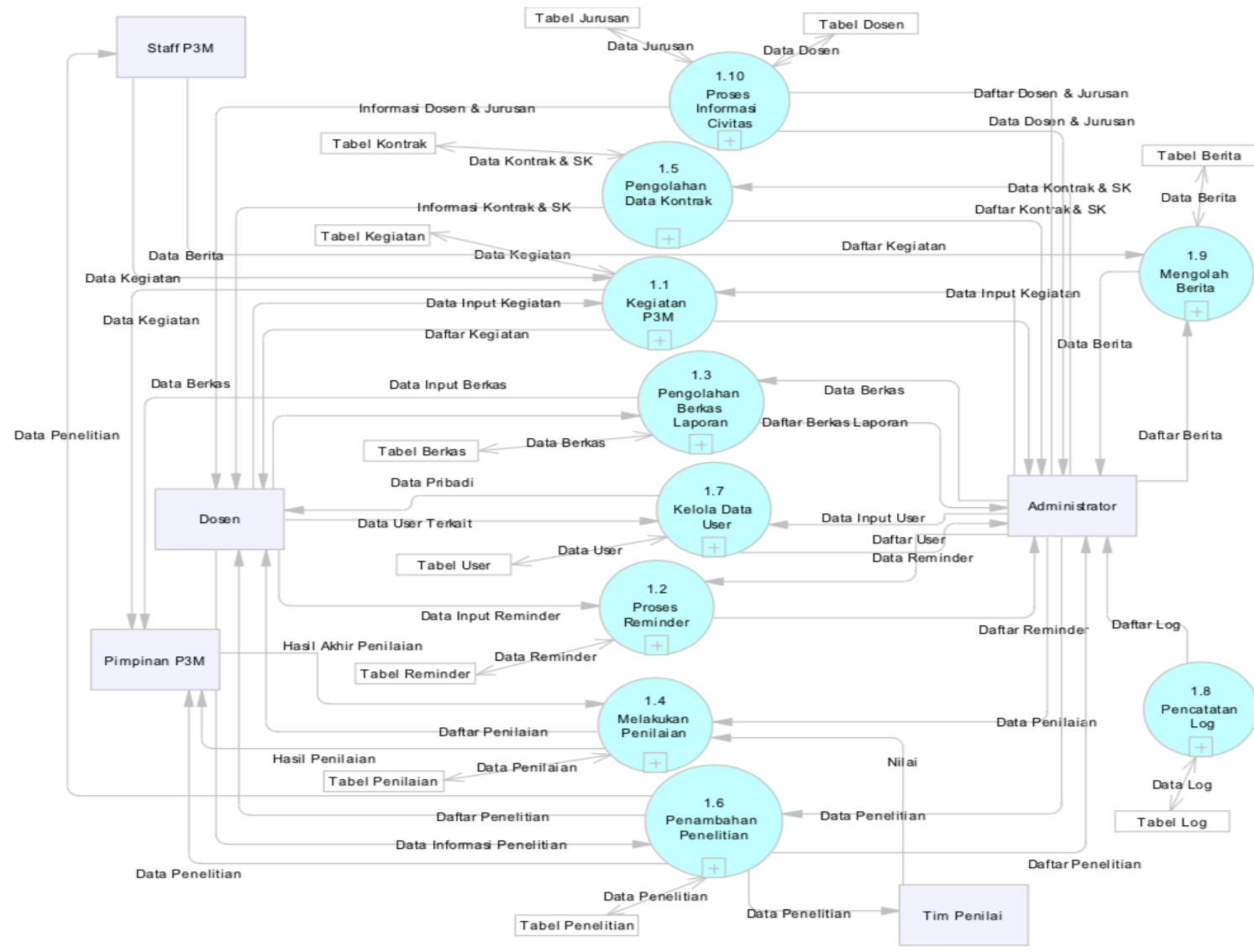

Gambar 7. Data Flow Diagram Level 1 Sistem Informasi Manajemen Penelitian di PENS

Conceptual Data Model (CDM)

Database adalah kumpulan data, umumnya mendeskripsikan aktivitas satu organisasi yang berhubungan atau lebih [18]. Penerapan database dalam sistem informasi disebut dengan sistem basis data yaitu suatu sistem informasi yang mengintegrasikan kumpulan dari data yang saling berhubungan satu dengan yang lainnya. Penerapan database biasanya dilakukan setelah melakukan analis terhadap sistem yang ada. Dalam pembuatan database dapat diawali dengan membuat desain pada tingkatan konseptual, yaitu disebut Conceptual Data Model (CDM). CDM mewakili struktur logika basis data secara keseluruhan, yang tidak tergantung atau terikat dengan perangkat lunak (software) maupun penyimpanan struktur data. Hal ini dapat memberikan gambaran formal tentang data - data yang dibutuhkan untuk menjalankan sebuah perusahaan ataupun aktifitas bisnis. [19]. CDM Sistem informasi manajemen kegiatan penelitian P3M PENS pada gambar 8. ERD SIM Pengabdian melibatkan 20 tabel diantaranya tabel dosen, user, role, berita, kontrak, jurusan, reviewer, berkas, penilaian, reminder, anggaran, log, kegiatan, tipe, menu, ajar, penelitian, pengabdian, seminar dan topik. Daftar tabel beserta fungsinya ditunjukkan pada tabel 2. 


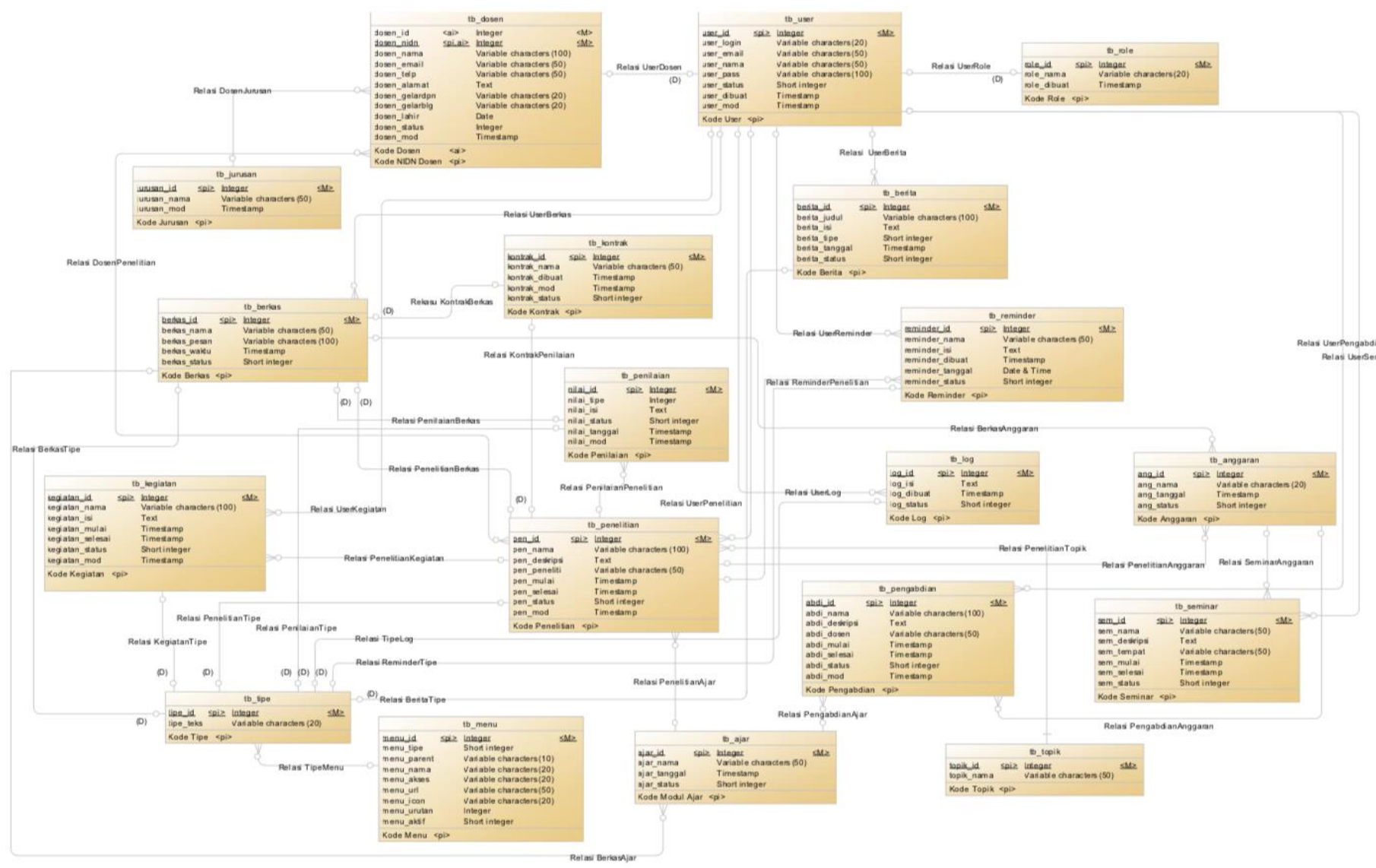

Gambar 8. CDM Sistem Informasi Manajemen Penelitian di PENS

Tabel 1. Daftar Tabel

\begin{tabular}{|l|l|l|}
\hline No & Entitas/Tabel & \\
\hline 1 & Dosen & Menyimpan data master dosen \\
\hline 2 & User & Menyimpan data master pengguna \\
\hline 3 & Role & Menyimpan data kategori pengguna \\
\hline 4 & Berita & Menyimpan data/informasi berita \\
\hline 5 & Kontrak & Menyimpan data kontrak penelitian \\
\hline 6 & Jurusan & Menyimpan data program studi dan jurusan di PENS \\
\hline 7 & Reviewer & Menyimpan data reviewer penelitian \\
\hline 8 & Berkas & Menyimpan data berkas seminar hasil \\
\hline 9 & Penilaian & Menyimpan data transaksi penilaian oleh reviewer \\
\hline 10 & Reminder & Menyimpan data reminder penelitian terhadap pelaksana \\
\hline 11 & Anggaran & Menyimpan data anggaran penelitian \\
\hline 12 & Log & Menyimpan laporan transaksi aktivitas yang dilakukan oleh pengguna \\
\hline 13 & Kegiatan & Menyimpan data kegiatan penelitian \\
\hline 14 & Tipe & Menyimpan data tipe kegiatan \\
\hline 15 & Menu & Menyimpan data menu \\
\hline 16 & Ajar & Menyimpan data buku/bahan ajar sebagai luaran penelitian \\
\hline 17 & Penelitian & Menyimpan data master penelitian \\
\hline 18 & Pengabdian & Menyimpan arsip pengabdian \\
\hline 19 & Seminar & Menyimpan data seminar sebagai luaran penelitian \\
\hline 20 & Topik & Menyimpan data topik kegiatan penelitian \\
\hline
\end{tabular}




\section{HASIL DAN PEMBAHASAN}

\subsection{Antarmuka Aplikasi}

Visualisasi aplikasi dapat dilihat dari tampilan antarmuka aplikasi. Antarmuka aplikasi yang pertama kali dilihat oleh pengguna ketika masuk ke dalam sistem adalah halaman dashboard. Halamandashboard berfungsi untuk menampilkan ringkasan dari beberapa data yang ada pada sistem ini, sesuai dengan role dari user tersebut. Tampilan halamannya ditunjukkan pada gambar berikut.
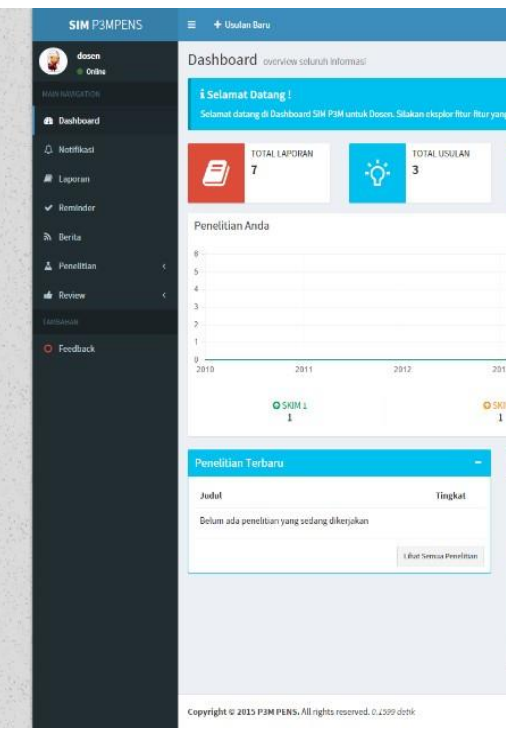

(a) Dashboard role dosen
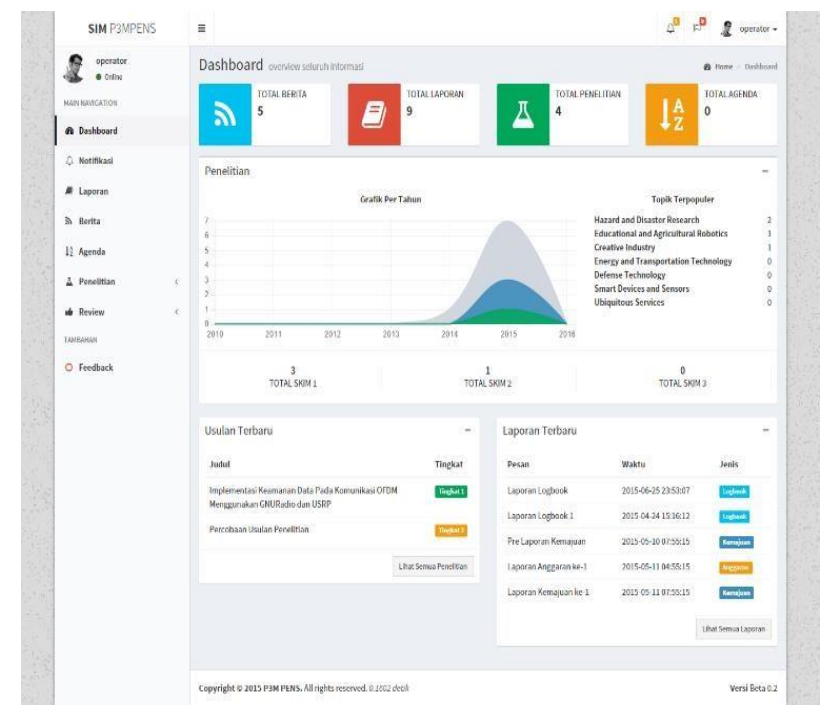

(b) Dashboard role operator

Gambar 9. Halaman Dashboard Pengguna

Salah satu fitur penting dalam aplikasi manajemen penelitian adalah penilaian proposal maupun laporan penelitian oleh reviewer sebagaimana ditunjukkan gambar berikut.

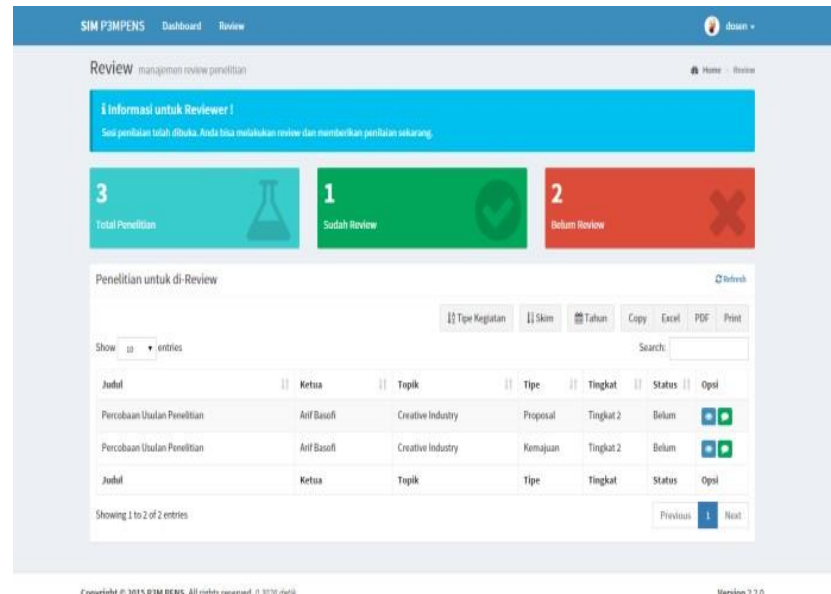

(a) Daftar Judul yang Direview

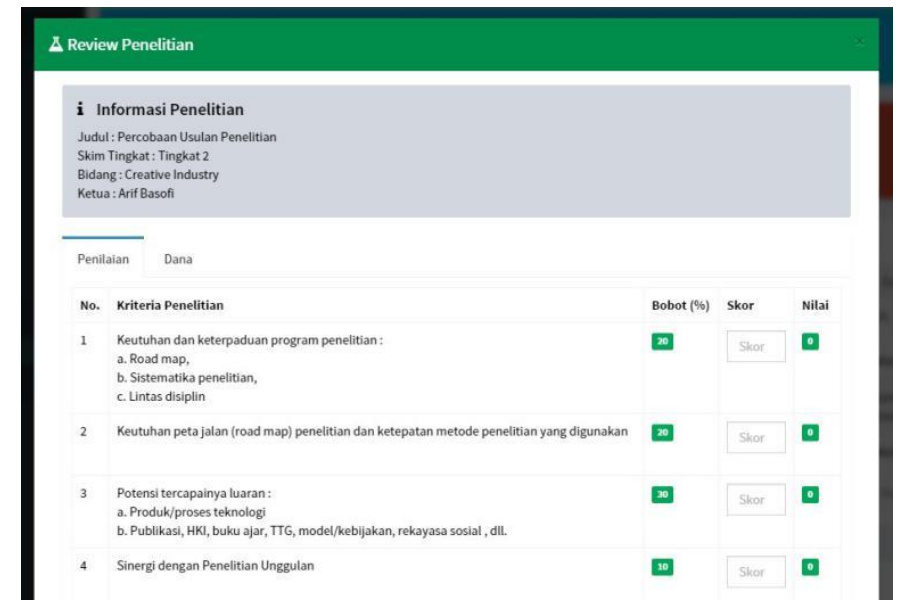

(b) Form Penilaian/Review

Gambar 10. Tampilan Proses Penilaian/Review 


\subsection{Pengujian Sistem}

Pengujian untuk antarmuka aplikasi ini menggunakan metode Black Box. Black Box Testing merupakan sebuah metode pengujian perangkat lunak dimana internal struktur, desain, dan implementasian dari suatu bagian yang sedang diuji tidak diketahui oleh pengujinya[20]. Hasil dari pengujian blackbox ditunjukkan pada tabel 2.

Tabel 2. Hasil Pengujian Validasi

\begin{tabular}{|c|c|c|c|}
\hline No. & Kasus Uji & Kondisi & Hasil \\
\hline 1. & Registrasi & $\begin{array}{l}\text { Useradmin dapat mendaftarkan usernamedan password bagi pengguna yang } \\
\text { belum pernah terdaftar. }\end{array}$ & Valid \\
\hline 2. & Login & $\begin{array}{l}\text { User dapat melakukan login dengan username dan password yang telah } \\
\text { terdaftar. }\end{array}$ & Valid \\
\hline 3. & CRUD User & Useradmin dapat menambah, merubah dan menghapus data user. & Valid \\
\hline 4. & Dashboard Admin & $\begin{array}{l}\text { Proses menampilkan dashboard user admin yang dapat melihat statistik jumlah } \\
\text { kegiatan penelitian per tahun dalam bentuk grafik dan per skim kegiatan } \\
\text { penelitian }\end{array}$ & Valid \\
\hline 5. & Log Admin & $\begin{array}{l}\text { Proses menampilkan halaman log admin yang dapat melihat riwayat aktivitas } \\
\text { semua pengguna }\end{array}$ & Valid \\
\hline 6. & Laporan Admin & $\begin{array}{l}\text { Proses menampilkan halaman laporan dari user admin yang dapat melihat semua } \\
\text { laporan penelitian yang diunggah oleh dosen }\end{array}$ & Valid \\
\hline 7. & CRUD Dosen & Useradmin dapat menambah, mengubah dan menghapus data dosen. & Valid \\
\hline 8. & $\begin{array}{l}\text { Dashboard } \\
\text { Operator }\end{array}$ & $\begin{array}{l}\text { Proses menampilkan halaman dashboard operator yang dapat melihat riwayat } \\
\text { dan statistik penelitian berdasarkan skim dan tahun }\end{array}$ & Valid \\
\hline 9. & Laporan Operator & $\begin{array}{l}\text { Proses menampilkan halaman laporan dari operator yang dapat melihat semua } \\
\text { laporan penelitian yang diunggah oleh dosen. }\end{array}$ & Valid \\
\hline 10. & $\begin{array}{l}\text { Halaman } \quad \text { Berita } \\
\text { Operator }\end{array}$ & $\begin{array}{l}\text { Proses menampilkan halaman berita dari operator dan user operator dapat } \\
\text { melakukan manajemen berita/informasi seperti: menambah, mengubah dan } \\
\text { menghapus berita. }\end{array}$ & Valid \\
\hline 11. & Unduh Laporan & Proses mengunduh laporan penelitian yang telah diunggah oleh dosen & Valid \\
\hline 12. & Ekspor Laporan & Proses mengekspor laporan dalam bentuk file excel dan pdf & Valid \\
\hline 13. & Unggah Panduan & $\begin{array}{l}\text { User operator mengunggah panduan penelitian yang selanjutnya dapat dilihat } \\
\text { oleh user dosen }\end{array}$ & Valid \\
\hline 14. & Plotting Reviewer & $\begin{array}{l}\text { User operator menampilkan halaman daftar judul proposal penelitian dan dapat } \\
\text { melakukan plotting } 2 \text { reviewer untuk tiap judul proposal penelitian }\end{array}$ & Valid \\
\hline 15. & List Reviewer & $\begin{array}{l}\text { Proses menampilkan daftar reviewer yang dapat dipilih sebagai reviewer untuk } \\
\text { suatu judul proposal penelitian }\end{array}$ & Valid \\
\hline 16. & Review Proposal & $\begin{array}{l}\text { Proses menampilkan halaman review proposal dari reviewer dan user dosen } \\
\text { sebagai reviewer dapat memberikan penilaian proposal penelitian yang diunggah } \\
\text { oleh peneliti/dosen }\end{array}$ & Valid \\
\hline 17. & $\begin{array}{l}\text { Review Laporan } \\
\text { Kemajuan }\end{array}$ & $\begin{array}{l}\text { Proses menampilkan halaman review laporan kemajuan dari reviewer dan user } \\
\text { dosen sebagai reviewer dapat memberikan penilaian laporan kemajuan penelitian } \\
\text { yang diunggah oleh peneliti/dosen }\end{array}$ & Valid \\
\hline 18. & Dashboard Dosen & $\begin{array}{l}\text { Proses menampilkan dashboard user dosen dan dapat melihat riwayat kegiatan } \\
\text { penelitian yang pernah dilakukan dosen tersebut }\end{array}$ & Valid \\
\hline 19. & $\begin{array}{l}\text { Halaman } \\
\text { Notifikasi Dosen }\end{array}$ & $\begin{array}{l}\text { Proses menampilkan halaman notifikasi dosen dan user dosen dapat melihat } \\
\text { semua status aktivitas dosen yang bersangkutan }\end{array}$ & Valid \\
\hline 20. & Laporan Dosen & $\begin{array}{l}\text { Proses menampilkan halaman laporan dosen dan user dosen dapat melihat semua } \\
\text { laporan yang pernah diunggah pada aplikasi }\end{array}$ & Valid \\
\hline 21. & Reminder Dosen & $\begin{array}{l}\text { Proses menampilkan halaman reminder dosen dan user dosen dapat melihat dan } \\
\text { melakukan manajemen reminder kegiatan }\end{array}$ & Valid \\
\hline 22. & $\begin{array}{l}\text { Halaman Berita } \\
\text { Dosen }\end{array}$ & $\begin{array}{l}\text { Proses menampilkan halaman berita dosen dan user dosen dapat melihat } \\
\text { informasi terbaru terkait kegiatan penelitian }\end{array}$ & Valid \\
\hline 23. & Unggah Proposal & $\begin{array}{l}\text { Proses menampilkan halaman unggah proposal dari user dosen dan user dosen } \\
\text { dapat mengunggah proposal penelitian. }\end{array}$ & Valid \\
\hline 24. & Usulan penelitian & $\begin{array}{l}\text { Proses menampilkan halaman pengusulan proposal penelitian dan dosen dapat } \\
\text { mengisi data usulan penelitian sebelum mengunggah proposal penelitian }\end{array}$ & Valid \\
\hline
\end{tabular}

Aspek kegunaan dalam desain antarmuka sistem dengan melakukan evaluasi antarmuka dan kesesuaian dengan prinsip-prinsip usability dari 10 evaluasi heuristik yang dikembangkan oleh Jacob Nielsen [21], telah menghasilkan beberapa hasil evaluasi yang ditunjukkan pada tabel 3 . 
Tabel 3. Pengujian Heuristik

\begin{tabular}{|c|c|c|c|}
\hline No. & Prinsip & Ada? & Bagai \\
\hline 1. & $\begin{array}{l}\text { Visibility of system } \\
\text { status }\end{array}$ & $\mathrm{Ya}$ & $\begin{array}{l}\text { Sistem sudah memberikan informasi/notifikasi ketika user sudah } \\
\text { membaca pesan notifikasi. }\end{array}$ \\
\hline 2. & $\begin{array}{l}\text { Match between } \\
\text { system and the real } \\
\text { world }\end{array}$ & Ya & $\begin{array}{l}\text { Sistem menggunakan bahasa Indonesia yang baku dan mudah } \\
\text { dipahami. }\end{array}$ \\
\hline 3. & $\begin{array}{l}\text { User control and } \\
\text { freedom }\end{array}$ & Ya & $\begin{array}{l}\text { User dapat menambah, mengubah, dan menghapus data. Tetapi } \\
\text { belum terdapat sistem untuk mengembalikan data yang telah dihapus. }\end{array}$ \\
\hline 4. & $\begin{array}{l}\text { Consistency } \\
\text { standards }\end{array}$ & Ya & $\begin{array}{l}\text { jilan pada suatu halaman memiliki } \\
\text { gg lain }\end{array}$ \\
\hline 5. & Error prevention & Ya & $\begin{array}{l}\text { Terdapat pesan error pada setiap user yang melakukan entri data } \\
\text { yang salah seperti salah memasukkan data konfirmasi password. } \\
\text { Serta ada pesan konfirmasi ketika akan menghapus data. }\end{array}$ \\
\hline 6. & $\begin{array}{l}\text { Recognition } \\
\text { than recall }\end{array}$ & $\mathrm{Ya}$ & $\begin{array}{l}\text { jilan menu halaman, karena sudah } \\
\text { inya. }\end{array}$ \\
\hline 7. & $\begin{array}{l}\text { Flexibility and } \\
\text { efficiency of use }\end{array}$ & Ya & $\begin{array}{l}\text { User diberikan kemudahan untuk memasukkan data seperti: } \\
\text { memasukkan data program studi melalui menu drop down sehingga } \\
\text { user tinggal memilih data yang tersedia. }\end{array}$ \\
\hline 8. & $\begin{array}{l}\text { Aesthetic and } \\
\text { minimalist design }\end{array}$ & Ya & $\begin{array}{l}\text { Desain sudah dibuat dengan sederhana seperti pewarnaan yang tidak } \\
\text { terlalu kontras. }\end{array}$ \\
\hline 9. & $\begin{array}{l}\text { Help users recognize, } \\
\text { diagnose, } \quad \text { and } \\
\text { recover from errors }\end{array}$ & Ya & $\begin{array}{l}\text { Terdapat pesan error serta info kesalahan apabila pengguna } \\
\text { melakukan kesalahan seperti ketika user salah memasukkan } \\
\text { password, kemudian sistem memberikan pesan kesalahan }\end{array}$ \\
\hline 10. & $\begin{array}{ll}\text { Help and } \\
\text { documentation }\end{array}$ & Tidak & $\begin{array}{l}\text { Tidak terdapat menu bantuan dan dokumentasi. Dokumentasi hanya } \\
\text { berbentuk buku. }\end{array}$ \\
\hline
\end{tabular}

\section{KESIMPULAN DAN SARAN}

Fitur-fitur sistem informasi manajemen penelitian ini dapat berjalan dengan baik serta memenuhi kualifikasi sesuai dengan prinsip-prinsip usability berbasis evaluasi heuristik dari Jakob Nielsen. Aplikasi ini memudahkan pihak pengelola penelitian institusi dan pihak peneliti dalam mengelola data kegiatan penelitian dan atributnya serta menangani berbagai permasalahan sebelumnya. Permasalahan yang dapat ditangani oleh sistem ini yaitu: (a)memudahkan dpendataan kegiatan penelitian, terutama dalam hal berkas dan data penting, (b)memudahkan dan mempercepat proses pengajuan usulan penelitian baru serta pelaporan data yang dilakukan secara berkala, (c)memudahkan untuk menetapkan tim penilai, (d)memudahkan penyimpanan data penelitian dan kegiatannya, (e)mempermudah dan mempercepat pengumpulan laporan penelitian, (f)memudahkan pengawasan terhadap kegiatan penelitian lokal, (g)memungkinkan data dapat diekspor menjadi berkas dokumen lain seperti bentuk pdf maupun xls serta dapat dicetak langsung, yang menjadikan tidak perlu membuat dokumen tersebut dari awal lagi.

Berdasarkan pengamatan lebih lanjut, terdapat beberapa yang masih dapat dikembangkan seperti diperlukannya notifikasi lanjutan berupa email atau mengimplementasikan push server, implementasi teknologi terbaru untuk meningkatkan kenyamanan pengguna, meningkatkan keamanan proses pembuatan dan penyimpanan data-data penting, serta pengembangan untuk meningkatkan kecepatan eksekusi proses sistem.

\section{DAFTAR RUJUKAN}

[1] Undang-Undang No. 20 Tahun 2003 tentang Sistem Pendidikan Nasional, Pasal 20

[2] Tripodi, Tony., Fellin, Phillip., Henry J. Meyer. (1996). The Assessment of Social Research. Illinois: F.E. Peacock Publishers.

[3] Hillway, Tyrus. Introduction to Research. Boston: Houghton Mifflin Company, 1956

[4] Undang-undang Nomor 12 Tahun 2012 tentang Pendidikan Tinggi Pasal 45

[5] J. H. Mustakini, Analisis dan Desain Sistem Informasi: pendekatan terstruktur teori dan praktek aplikasi bisnis, Yogyakarta: Andi, 2005.

[6] Stair Ralph, Reynold Goerge. (2008).Principles of Information System a Managerial. Thomson course Technology : Canada. 
[7] Kroenke, D M. (2008). Experiencing MIS. Prentice-Hall, Upper Saddle River, NJ

[8] O'Brien, J A. (2003). Introduction to information systems: essentials for the e-business enterprise. McGraw-Hill, Boston, MA

[9] Alter, S. The Work System Method: Connecting People, Processes, and IT for Business Results. Works System Press, CA

[10] E. Hartati, "WEBSITE PELAPORAN KINERJA PENELITIAN DAN PENGABDIAN MASYARAKAT PADA LEMBAGA PENELITIAN DAN PENGABDIAN MASYARAKAT STMIK PALCOMTECH PALEMBANG," Sistem Informasi, STMIK PalComTech Palembang, p. $1,2014$.

[11] Solichin, Achmad. 2010. Pemrograman Web dengan PHP dan MySQL. Universitas Budi Luhur, Jakarta. $122 \mathrm{hlm}$.

[12] Kadir, Abdul. 2004. Mudah mempelajari database MySQL. Penerbit ANDI, Yogyakarta. $220 \mathrm{hlm}$.

[13] Lerdorf, Rasmus. 2002. PHP - Advanced Tutorial Gulev. Veracruz, Mexico. 80 hlm.

[14] Wardana, S.Hut., M.Si.,2010, "Menjadi master PHP dengan Framework Codeigniter". Jakarta: Elex Media.

[15] Almas Rahmah Arimi Shodiq "Sistem Informasi Penelitian dan Pengabdian Masyarakat sesuai Standar BAN-PT", Tugas Akhir, Teknik Informatika, Fakultas Sains dan Teknologi UIN Maulana Malik Ibrahim, Malang, 2013.

[16] Ivan Williandy, Helmy Fitriawan, Raden Arum SP3 "Rancang Bangun Sistem Informasi Penelitian dan Pengabdian Kepada Masyarakat Fakultas Teknik Universitas Lampung Menggunakan PHP dan MySQL" ELECTRICIAN - Jurnal Rekayasa dan Teknologi Elektro, Volume 10, No. 3, September 2016.

[17] Desi Ratnasari, Hilmy Abidzar Tawakal, "Analisis Dan Perancangan Aplikasi Sistem Informasi Penelitian Dan Pengabdian Masyarakat LPPM STT TERPADU NURUL FIKRI" , Jurnal Informatika Terpadu, STT Nurul Fikri, 2017.

[18] Ramakrishnan, R, dan Gehrke, J., 2003, Sistem Manajemen Database (Terjemahan), Edisi ketiga, Andi Offset. Yogyakarta

[19] Winarko, Edi, 2006, Perancangan Database dengan Power Designer, PrestasiPustaka, Jakarta.

[20] http://softwaretestingfundamentals.com/black-box-testing/, dikutip tanggal 16 Oktober 2019.

[21] Nielsen, Jakob (1994). Usability Engineering. San Diego: Academic Press. pp. 115-148. ISBN 012-518406-9. 